\title{
Research Results Transfer towards the Productive Sector via Research Collaboration in Four Colombian Public Universities
}

\author{
María Eugenia Morales Rubiano ${ }^{1 *}$, Pedro Emilio Sanabria Rangel1, Paola Andrea Plata Pacheco ${ }^{1}$, \\ Fabian Arley Ninco Hernández ${ }^{1}$
}

\begin{abstract}
This article shows the determining factors in the research results transfer towards the productive sector via research collaboration in four Colombian public universities. Thirty heads of units in the aforementioned universities were interviewed, which served to determine eleven cases of study and conduct interviews with thirty-five participants ranging from researchers, participant in formation and business people, in each case, it was found that especially in the last decade universities have turned to creating capacities for research collaboration as well as an openness in participants to create links that not only go in favor of enriching the productive sector but also in strengthening formation and research processes. It was concluded that there is a recent growing interest in the different actors in strengthening the bonds between the universities and the productive sector, though there may be some difficulties in the process of research collaboration due to the lack of an appropriate regulatory framework.
\end{abstract}

Keywords: University-Industry relations; R\&D transfer; research collaboration; public universities; case-studies; Colombia.

Submitted: August 25th 2015 / Approved: December 1st 2015

\section{Introduction}

The university, as a producer and transmitter of knowledge, has generated strategies to bond itself to its surroundings and strengthen social and productive organizational capacities. Historically, universities have undergone the aforementioned process through teaching and research, but in these functions, the production of knowledge most of the time happened in isolation from the real social context. With the rise of the "third mission", universities have started to make active links with organizations through diverse transfer dynamics so that the generated knowledge gets social applications (Lee, 1996; Davies et al., 2008; D’Este \& Patel, 2007).

Among the strategies to transfer knowledge to the surroundings there is the university-productive sector relationship (U-PS/R) which seeks to contribute to the economic development of organizations as well industrial competitiveness (Geiger \& Creso, 2005; Markman et al., 2005). This relationship is also the result of the permanent need of organizations to belong to an economic system that revolves around innovation and competitiveness. This way, the close relationship between science and technology is taken advantage of, as well as the diverse sources of innovation and the creation of internal knowledge networks to set up mechanisms, channels or relationships between different actors towards knowing and promoting organizational innovation processes (D'Este \& Patel, 2007; Meyer-Krahmer \& Schmoch, 1998; Perkmann \& Walsh, 2007).

The university, as an actor in systems of innovation and in compliance with the requirements of society has generated an internal structure devoted to research, development and innovation processes $(\mathrm{R}+\mathrm{D}+\mathrm{I})$ including groups, institutes and research centers that allow to set up communication channels for transferring research results to the surrounding environment.

Among the various bonding dynamics that make up for the use of research results in organizations, there is Research Collaboration (RC) which implies several research organizations, technological development and/or the productive sector in $(\mathrm{R} \& \mathrm{D}+\mathrm{I})$ activities with high exploitation potential; each participant commits to the collective in giving resources and/or research efforts towards project development while seeking to increase competitive advantages and serve as an economic growth engine (OECD, 2004; D’Este \& Patel, 2007; Ponomariov \& Boardman, 2008).

Y. S. Lee (1996) points that RC activities are one of the most effective means to accelerate result flow to the surroundings, especially in the productive sector. Meyer-Krahmer and Schmoch (1998), in a Germany-based study, confirm that the two-way relationships (such as $\mathrm{RC}$ activities) are seen by academic researchers as "more interesting" since its level of complexity require a cooperation between the university and the industry and an information exchange between the actors that make them more relevant than those who are lineal or unidirectional. In spite of this, there are many more studies on other transfer channels (such as the commercialization of industrial property or academic entrepreneurship) than in U-PS/R that stem from $\mathrm{RC}$, this due to the difficulty of accessing parametrized information (Perkmann \& Walsh, 2007; Meyer-Krahmer and Schmoch, 1998).

In the Latin-American scenario, success cases like Mexico, Brazil and Chile have set the foundation to form a commitment between the different actors in the innovation system that ease U-PS/R and imply a significant change in the traditional conditions of the Latin-American

1 Grupo de Estudios Contemporáneos en Contabilidad Gestión y Organizaciones, Faculty of Economic Sciences,

Universidad Militar Nueva Granada, Bogotá, Colombia.

*Corresponiding author: maria.morales@unimilitar.edu.co 
University oriented exclusively to solving social problems (Cabrero et al., 2011; Saavedra, 2009)

Even though Colombia has seen a significant increase in the U-PS/R, it has not generated definitions on internal research capabilities, formation and extension in academia that allows generating strategies that strengthen and encourage specialization in certain areas of innovation (Pineda et al., 2011). Though some universities have implemented structures that make the relationship with their surroundings easier, there still are not surveys on U-PS/R and almost no studies on the determining factors for knowledge transfer from them to the outside. The aim is to pinpoint those factors that make research result transfer via research collaboration (RTRC) to the productive sector possible in some outstanding cases in four public universities in Colombia, so that the actors of these systems take action in improving $\mathrm{U}-\mathrm{PS} / \mathrm{R}$ in the country.

This document initially describes $\mathrm{RC}$ as one of the most effective strategies in research result transfer (RRT) as well as the factors identified on it as part of a bibliographic review. It goes on to present the research method based on four university cases under the factors found in the aforementioned review, then the results are presented in a way that shows the determining factors for RC in each university and finally, the deciding factors for RC in the practices of the Colombian universities that were subjected to this study.

\section{General Framework}

Collaborative Research as a university-productive sector bidirectional binding strategy

When adopting the third mission, one of the more pressing commitments that the university had acquired has been the transferring academic research results to the productive sector as means to support economic growth. The existence of communities (producers and users of knowledge) urges to generate different types of interaction between them (linear push/pull - bidirectional) (Davies et al., 2008; Perkmann \& Walsh, 2007).

Linear interactions cause some problems: the push model needs to be achieved by attracting a business towards the offer of knowledge in the university and the pull model tries to avoid skewing the advances of science since research is hired by the productive sector with a particular interest (Lee, 1996; Meyer-Krahmer \& Schmoch, 1998; Perkmann \& Walsh, 2007; D’Este \& Patel, 2007; Davies et al., 2008). Research Collaboration can be found under bidirectional interactions, it implies joint work among several organizations in developing $\mathrm{R} \& \mathrm{D}+\mathrm{I}$ projects with a high exploitation potential in the productive sector; participation can happen through resources and/or research efforts (OECD, 2004; D'Este \& Patel, 2007; Ponomariov \& Boardman, 2008). This model's advantage is the start of a relationship which can begin via informal means, with the creation of knowledge networks originated in conferences and research publishing to later become more formal in a long-term relationship (Meyer-Krahmer \& Schmoch, 1998).

Table 1 shows a synthesis of goals, methodology and results made in international settings that sought to identify the channels and factors that are present in the University/Industry relationship (U/I R) based on national surveys, collaborative comes out as the most efficient result transference mechanism.

Table 1. International referents on U/I Linking

\begin{tabular}{|c|c|c|c|}
\hline Author & Objective & Methodology & Results \\
\hline Y. S. Lee (1996) & $\begin{array}{l}\text { Finding technology transfer } \mathrm{U} / \mathrm{I} \\
\text { interaction mechanisms in the } \\
\text { United States }\end{array}$ & $\begin{array}{l}\text { Information obtained through a survey of } 1000 \\
\text { members of American universities intensively } \\
\text { engaged in research is discussed. }\end{array}$ & $\begin{array}{l}\text { When comparing } 1990 \text { results with results from } \\
\text { the previous decade, researchers have a greater } \\
\text { disposition to work side-by-side with the industry }\end{array}$ \\
\hline $\begin{array}{l}\text { D'Este and Patel } \\
\qquad(2007)\end{array}$ & $\begin{array}{l}\text { Identify channels that rely on the } \\
\text { variety of U/I interactions in The } \\
\text { United Kingdom }\end{array}$ & $\begin{array}{l}\text { Identify U/I transference channels from surveys } \\
\text { to academic researchers in the United Kingdom }\end{array}$ & $\begin{array}{l}\text { U/I interactions are present in several } \\
\text { communication channels, being more common } \\
\text { those in consulting, research contracts, collaborative } \\
\text { research and training }\end{array}$ \\
\hline $\begin{array}{l}\text { Perkmann and Walsh } \\
\qquad(2007)\end{array}$ & $\begin{array}{l}\text { Establish a research base to } \\
\text { promote } \mathrm{U} / \mathrm{I} \text { interactions } \\
\text { oriented to innovation }\end{array}$ & $\begin{array}{l}\text { A new framework is proposed to distinguish U/I } \\
\text { relationships from diverse mechanisms such as } \\
\text { technology transfer and mobility through } \\
\text { bibliographic review. Mechanisms that stem } \\
\text { from practices are analyzed. }\end{array}$ & $\begin{array}{l}\text { Research concludes that U/I interactions are } \\
\text { a common practice and different transference } \\
\text { channels depend on the industries and scientific } \\
\text { disciplines. }\end{array}$ \\
\hline $\begin{array}{l}\text { Meyer-Krahmer and } \\
\text { Schmoch (1998) }\end{array}$ & $\begin{array}{l}\text { Gather empirical evidence } \\
\text { from U/I Interactions on } 4 \\
\text { technological areas based on } \\
\text { basic and applied sciences in } \\
\text { Germany }\end{array}$ & $\begin{array}{l}\text { From discussions around a survey in German } \\
\text { Universities, bibliographic review and primary } \\
\text { information gathering, evidence of U/I } \\
\text { interactions was sought }\end{array}$ & $\begin{array}{l}\text { It was found that the robust innovation system } \\
\text { in Germany was a result of the strong interaction } \\
\text { between science-based areas and the impact they } \\
\text { have had in the industry. This impact generates } \\
\text { U/I cooperative relationships for continuity, } \\
\text { development and economic development. }\end{array}$ \\
\hline
\end{tabular}




\section{Research results transfer via research collaboration driving factors}

Through documentation and existing studies on RC six categories for analysis and study of $\mathrm{R} \& \mathrm{D}+\mathrm{I}$ are presented: $\mathrm{R} \& \mathrm{D}$ transfer approach, linking units and transfer mechanisms, characteristics of the actors (researcher, university, unit personnel, participant in formation and benefiting organization), R\&D process, internal capabilities of the university and surroundings conditions (organization, State and society); that gather the different driving factors for executing RC processes and that represent the reference framework for this research (table 2).

Table 2. Result Transfer Factors on Collaborative Research Transference

\begin{tabular}{|c|c|}
\hline Category & Subcategory \\
\hline \multirow{2}{*}{ R\&D Focus } & Social and economic development transfer focus \\
\hline & Social and cultural development transfer focus \\
\hline \multirow{2}{*}{ Liaison or linking unit, mechanisms } & Link or transfer unit type \\
\hline & Linking Mechanisms \\
\hline \multirow{8}{*}{ Actor's Characteristics } & Innovator Profile \\
\hline & Innovator's position and capabilities on technology transfer \\
\hline & Linking unit Personnel's profile \\
\hline & University's profile \\
\hline & Participating organization's profile \\
\hline & Beneficiary's position and capabilities \\
\hline & Student profile \\
\hline & Student's position and capabilities \\
\hline \multirow{6}{*}{ R\&D Process } & R\&D Motivation \\
\hline & R\&D Formulation/Planning \\
\hline & Actor's participation in R\&D Processes \\
\hline & R\&D Development and Execution \\
\hline & Transfer Status \\
\hline & R\&D appropriation and Transfer \\
\hline \multirow{3}{*}{ Internal Capabilities (University) } & Policies oriented to collaborative research and knowledge transfer \\
\hline & Resources oriented to collaborative research and knowledge transfer \\
\hline & University's perspective on collaborative research and knowledge transfer \\
\hline \multirow{3}{*}{ Surroundings Conditions } & Organization's conditions \\
\hline & State Conditions \\
\hline & Society Conditions \\
\hline
\end{tabular}

\section{Method}

An exploratory and qualitative research was conducted, taking the multiple-case study as the method. Four (4) cases in Colombian public universities were taken into account: Universidad del Valle in Cali, Universidad Nacional de Colombia in Bogotá and Medellín, Universidad Militar Nueva Granada in Bogotá and Universidad de Antioquia in Medellin which for the purposes of this study were labeled with letters (A, B, C, D, respectively). University B is located in several places of the country which makes up for a better and richer comparison of practices, having said this, two of the units for this university were labeled as B1 and B2 respectively.

For each university cases, where RC took place, were taken into account, specifically in the engineering and basic - applied sciences areas for being frequent places of interaction for this type of research 
mode. The last five years (2009-2013) were taken as time frame and the selection of these cases was made by interviewing 30 heads of linking units (heads of transfer, research or extension units, research group directors or research center/institute directors, see table 3) whose knowledge and experience brought a general perspective on the characterizing factors for RTCR in their respective universities.

The study was performed in 11 cases which meant that a contact with those who participated was made in order to gather their experiences.
For each case an interview was set for the head of research, who was the person in charge of leading the project from the academic perspective; another interview for a participant in formation linked to the project who served for gathering the research student or young researcher or research assistant point of view, and one for the industry/organization representative which participated or was benefited from the knowledge and development generated. This made up for a total of 35 participants (table 3 ).

Table 3. Transfer process actors interviewed per university

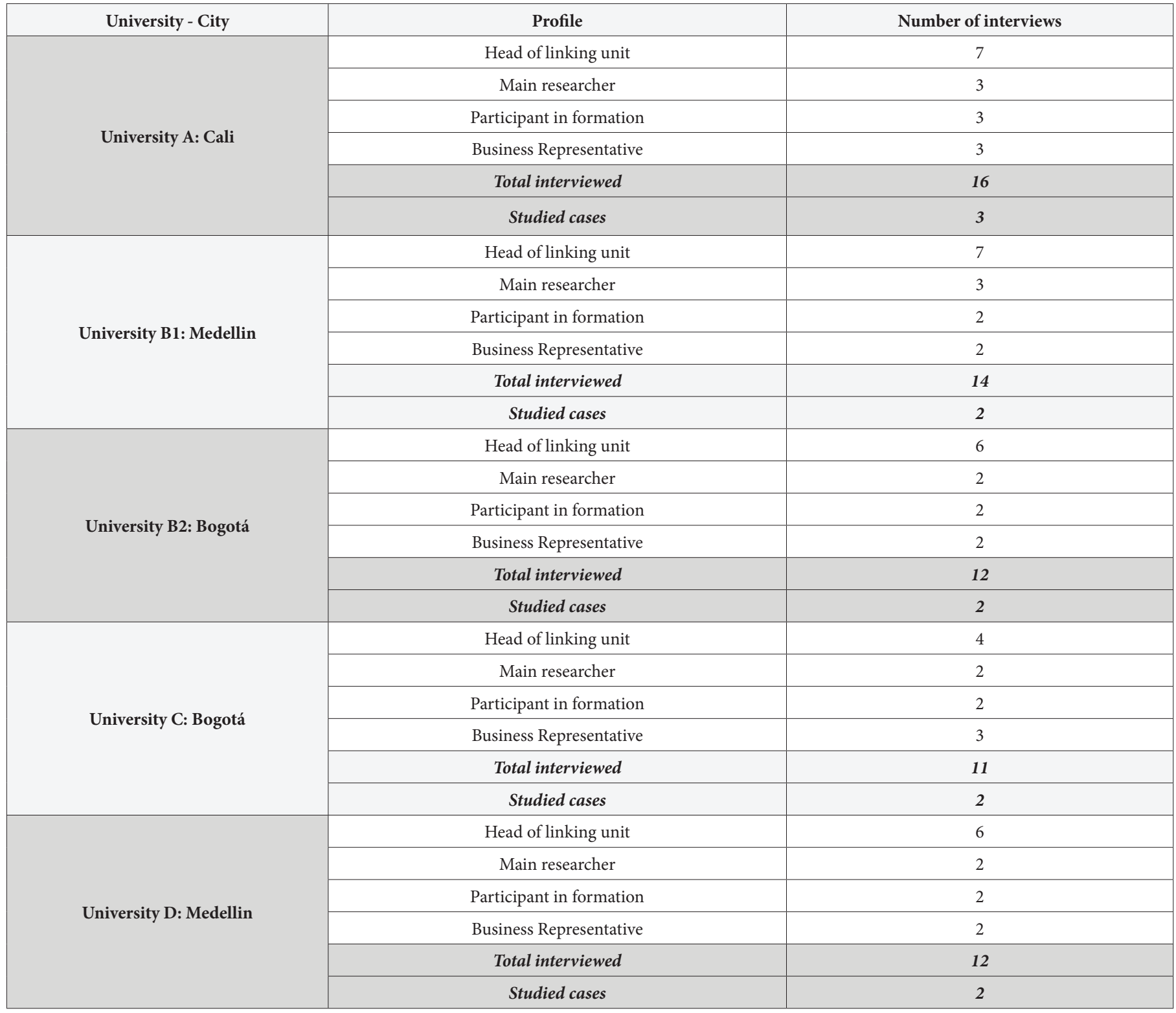

The interviews were structured according to the categories and factors reference frame (table 3) which was made up from a bibliographic review on the subject. The instrument meant to gather data by formulating semi-structured open questions on the incidence of certain aspects for RTRC, according to the literature (studies and national as well as international experiences) in elaborating an instrument that considered each participant was aware of the processes and points of view and for that matter, interview scripts were constructed for each type of participant. 
For the analysis of the information gathered, the discourse analysis technique was employed, powered by the NVivo 9 software. The interviews were then, transcribed and categorized in order to obtain a reference count that made the identification of repeating factors in the interview possible. Selection of the determining factors was made by taking the higher reference count for category in at least three of the universities since this implies that all parts acknowledge these conditions as relevant when it comes to the process of collaborative research between the university and the productive sector.

\section{Results}

\section{Scope and transfer profile}

When mentioning the scope, interviewees point out that the scope of a research-oriented to research and development (R\&D) jointly with the productive sector (Acevedo et al., 2005; Heidrick et al., 2005) however, they also mention scientific and technical training of personnel as an important factor (Geiger \& Creso, 2005) (fig. 1).

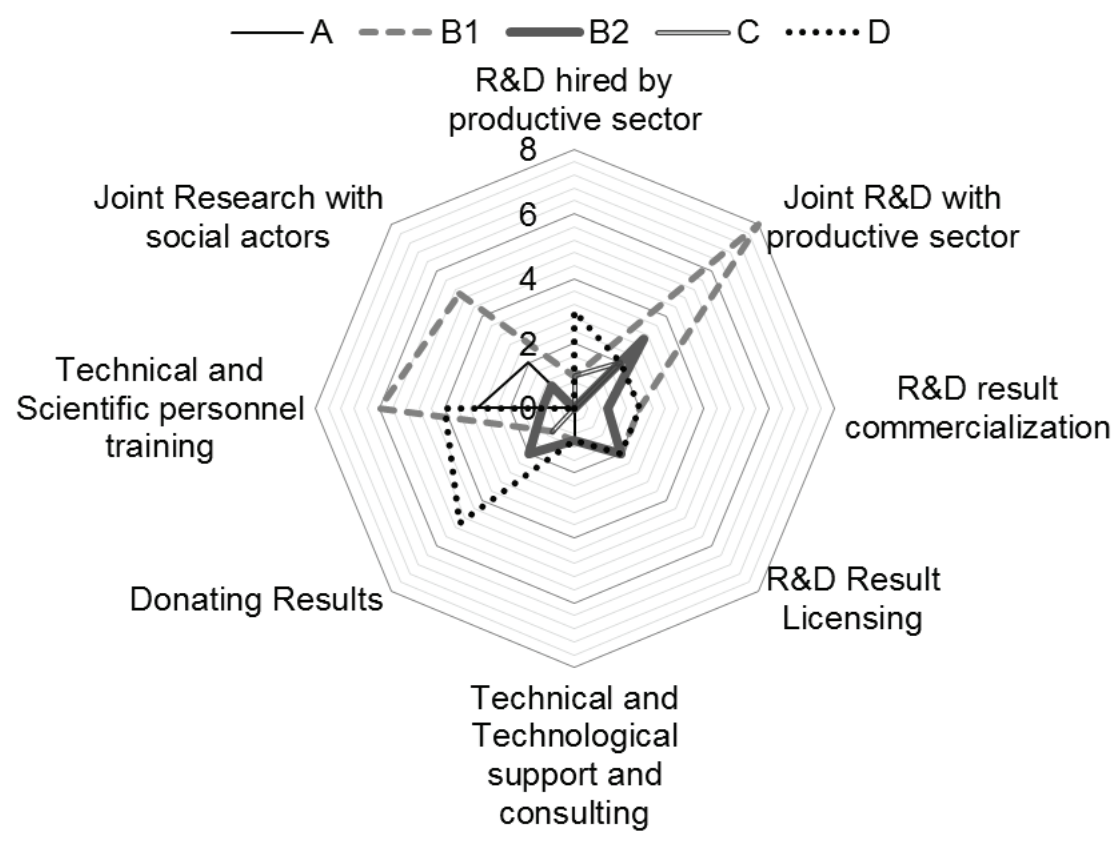

Figure 1. $\mathrm{R}+\mathrm{D}$ transfer approach

Interviewees from universities $\mathrm{A}$ and $\mathrm{B} 1$ make reference on joint research with social actors (Baird, 2003) while university D sees in donating $\mathrm{R}+\mathrm{D}$ results (Arias \& Aristizabal, 2011) as a mean for achieving developments. Universities B1, B2, and D take for licensing R\&D results; however, this and other factors related to an economic approach (Acevedo et al., 2005) as well as R\&D contracted by the productive sector, commercialization of R\&D results and technical and technological consultancy and support (Garcia, 2008) do not show up in this category.

In reference to the university profile, University D shows itself as a social and entrepreneurial institution (Fernández et al., 2000) which shows that the university is making efforts from within and from several different focuses to build better bridges with its surroundings, since both these profiles bring a strong connotation in the university's role as an active member in society.

On the other hand, universities, A, B1, B2, and C see themselves as traditional institutions (Decter et al., 2007; Fernández et al., 2000), this means that they center their activities in teaching and research. Finally, from this first category family we can come to the conclusion that in spite of the bias there might be towards an economic focus due to the deliberate selection of cases where there has been collaboration with the productive sector, it is relevant for public universities to transfer their results to its surroundings for economic gain, but without leaving behind its mission of scientifically and technically forming those who take part in said processes. 


\section{Linking units and mechanisms}

The interviewees show that universities where there are different linking units, but the three that were referenced the most were research groups, national-level units (COLCIENCIAS, INNPULSA, and Ministries) and internal units that support transference processes (table 4).

Table 4. Linking units by University

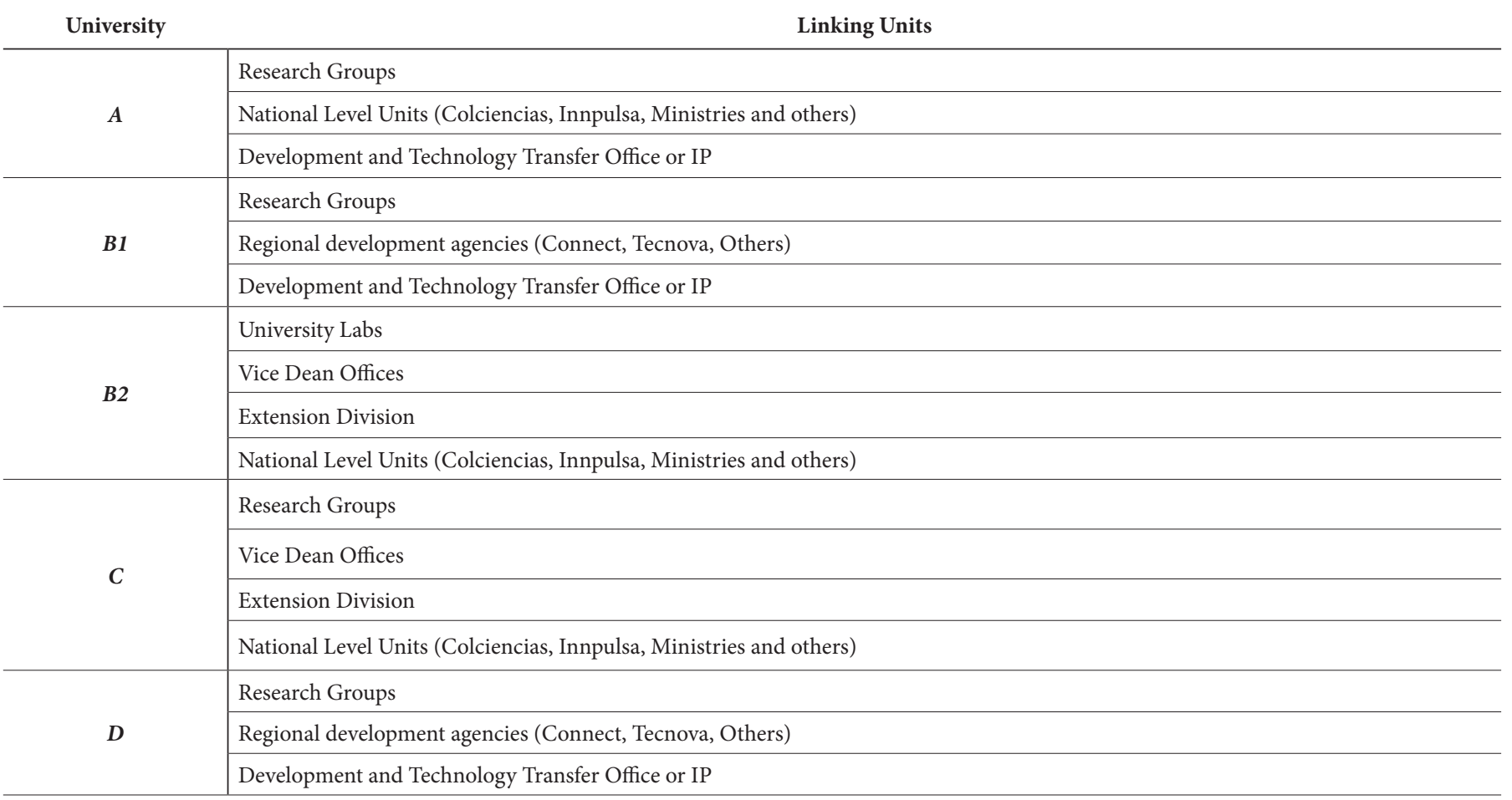

${ }^{*}$ Colciencias is the national administrative department in science, technology and innovation of Colombia,

${ }^{* *}$ Innpulsa is a government institution established in February 2012 to support and promote extraordinary entrepreneurial growth.

${ }^{* * *}$ Ministries make especial reference to Rural Development and Agriculture, Commerce, Industry and Tourism Ministries of the Colombian Government.

$\dagger$ Connect and Tecnova are technology transfer offices of the regional government in the cities of Bogotá and Medellin, respectively

According to the profile of the personal that works in the linking or transfer units, for the universities, the main input comes from those who do RTCR (Table 5). In general, it comes to attention the work they do to integrate a research group with an industry one (Siegel et al., 2004; Bjerregaard , 2009) and the knowledge the links bring into bargaining processes (Gertner et al., 2011; Markman et al., 2005).

Table 5. Linking unit personnel profile per university

\begin{tabular}{c|l} 
University & Linking unit personnel profile \\
\hline \multirow{A}{*}{$\boldsymbol{B} 1$} & $\begin{array}{l}\text { Scientific knowledge } \\
\text { Seeks to integrate a research group with an industry one } \\
\text { Knowledge about intellectual property (IP) }\end{array}$ \\
\hline \multirow{3}{*}{$\mathbf{B 2}$} & $\begin{array}{l}\text { Legal Knowledge } \\
\text { Seek to integrate a research group with an industry one } \\
\text { Negotiation Background }\end{array}$ \\
\hline $\boldsymbol{C}$ & $\begin{array}{l}\text { Seek to integrate a research group with an industry one } \\
\text { Knowledge on bargaining } \\
\text { Technology Assessment Knowledge }\end{array}$ \\
\hline $\boldsymbol{D}$ & Seek to integrate a research group with an industry one \\
\hline
\end{tabular}


From the previous statements, it can be inferred that the different internal and external units which universities have to interact with their surroundings are working to be a complement in research when it comes to dealing with the productive sector, and are a key factor in matters like compatibility, business culture and bargaining processes in results.
When speaking of linking mechanisms, the interviewees emphasize that a relationship with the productive sector starts in an informal setting (Arvanitis et al., 2011; Ponomariov \& Boardman, 2008; Siegel et al., 2004) to later formalize agreements, contracts and cooperation (Arvanitis et al., 2011; Siegel et al., 2004; Ramos-Vielba \& Fernández-Esquinas, 2012) for university B, internal and externals callings (Vestergaard, 2005) serve as linking mechanism (fig. 2).

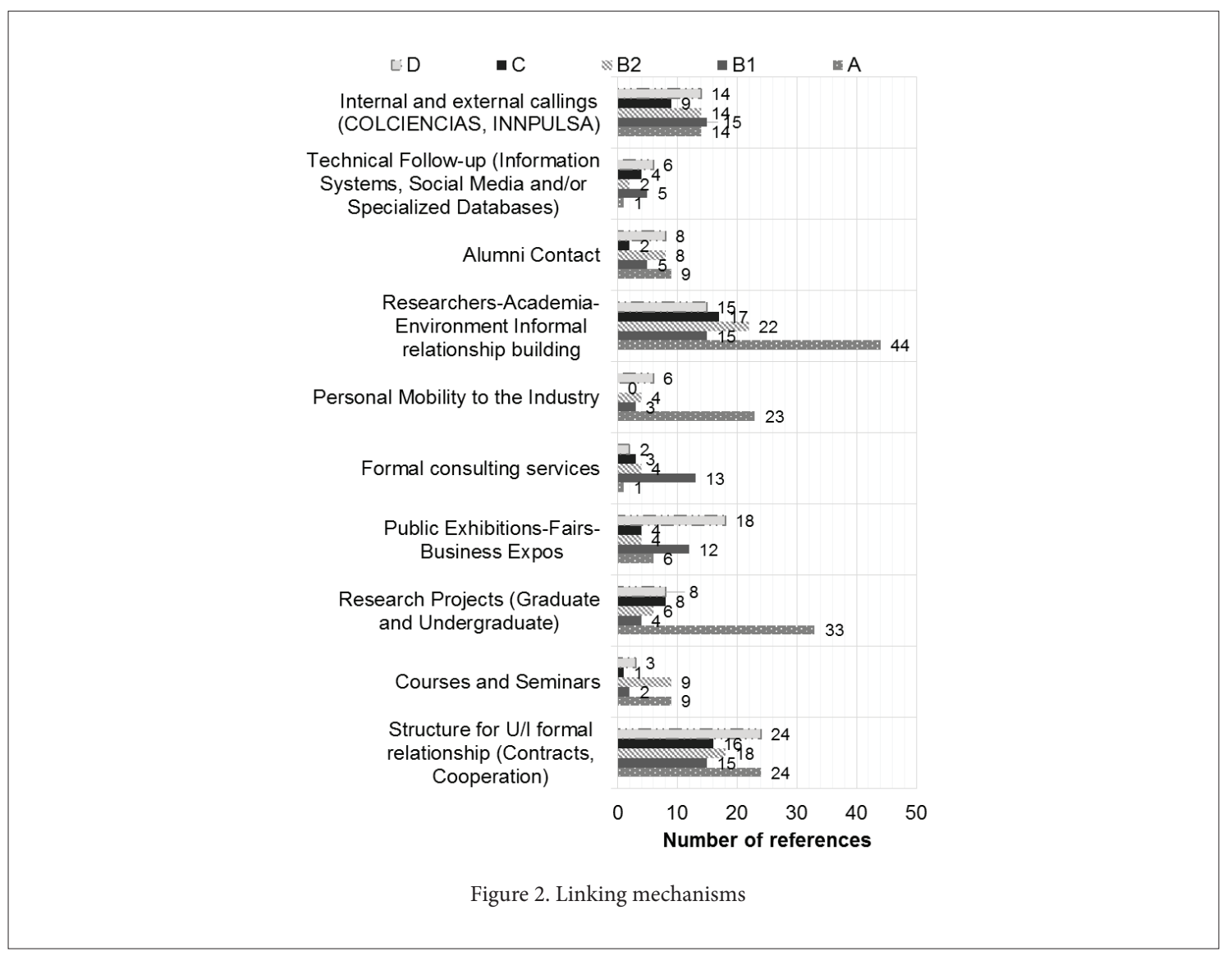

In particular terms, for University A, the most important linking mechanism is dissertation projects from students and for university $\mathrm{D}$, public exhibitions such as fairs, business conferences (Siegel et al., 2004) stand at the top of their list.

From these results, it can be observed that for implementing RTRC processes, universities not only need support from their linking or transfer units (internal or external) but it is vital for them to develop mechanisms in which strategies come from informal settings (centered around the researcher) to later get to formal actions that are handled at an institutional level.

\section{Participant Characteristics}

In table 6, results for profile, position and researcher's motivation are gathered for each of the universities that participated in the study. A growing relationship between the researcher and the productive sector is evidenced in this table (Colyvas, 2007; Krucken et al., 2007; Siegel et al., 2004, Bozeman, 2000; Vestergaard, 2007) this is also shown in the results on mechanisms that indicate that a link stems from informal settings as well as in a profile-oriented to contribute with the productive sector (Lakpetch \& Lorsuwannarat, 2012), seeking to apply knowledge in a real context (Lee, 2000; Azagra , 2003) without leaving the scientific formation of students behind (Geiger \& Creso, 2005; Vestergaard , 2007). 
Table 6. Profile, position and researcher's motivation

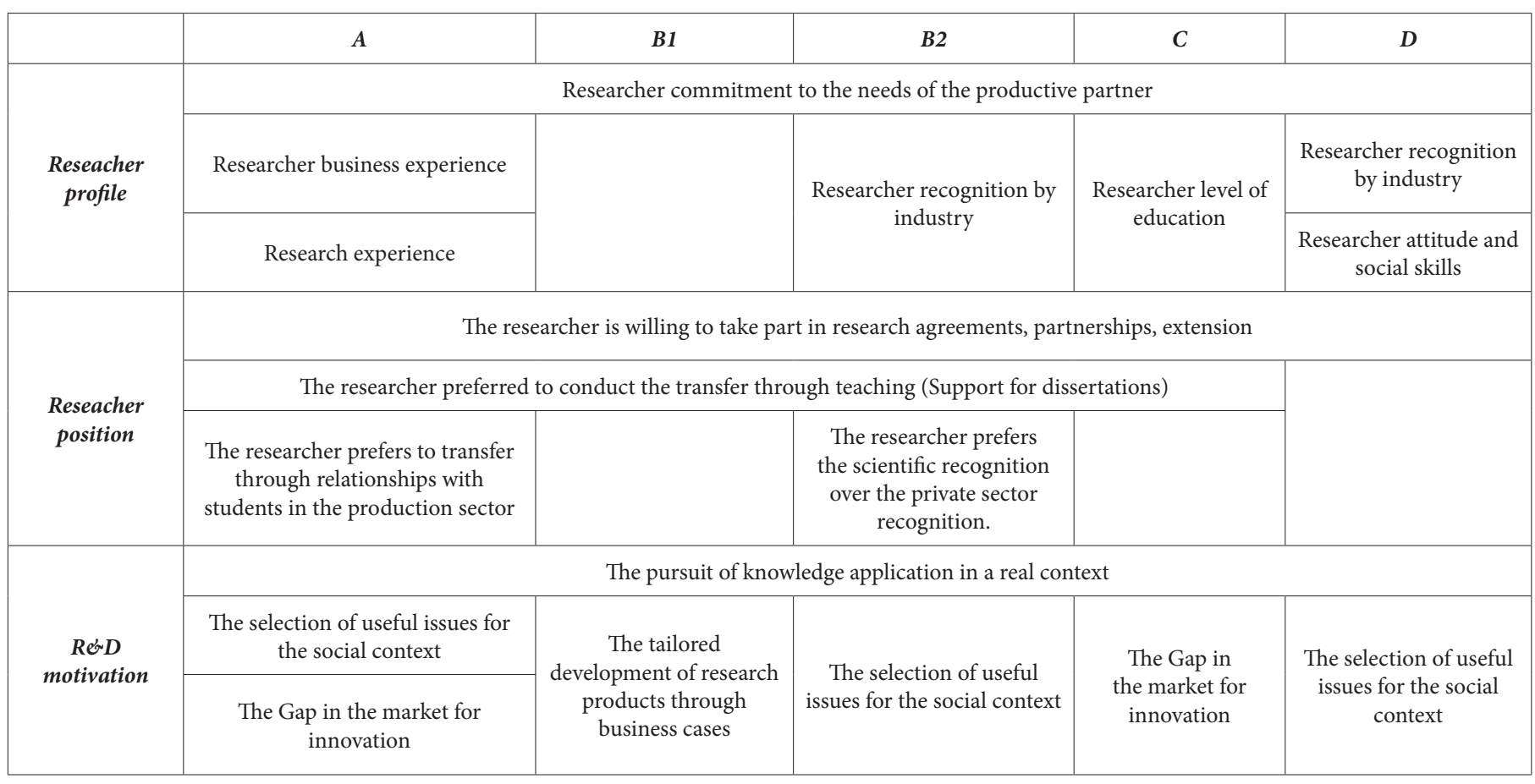

When referring to the participant in formation position (young researcher, research assistant or student researcher), three universities $(\mathrm{B}, \mathrm{C}$ and $\mathrm{D})$ met the role of generating relationships with the benefiting institution (Silvernagel et al., 2009) which means that during their relationship with the project the interaction was made mainly with the industry. Another aspect of this is their motivation take on the project (fig. 3). University A showed as a means to make a career in the organization (Thune, 2009) whereas in university D, RC is just a means to start up a career in research (Thune, 2009).

For most of the interviewees, having taken part in the projects gave them the opportunity to apply what they had learned in a real setting.

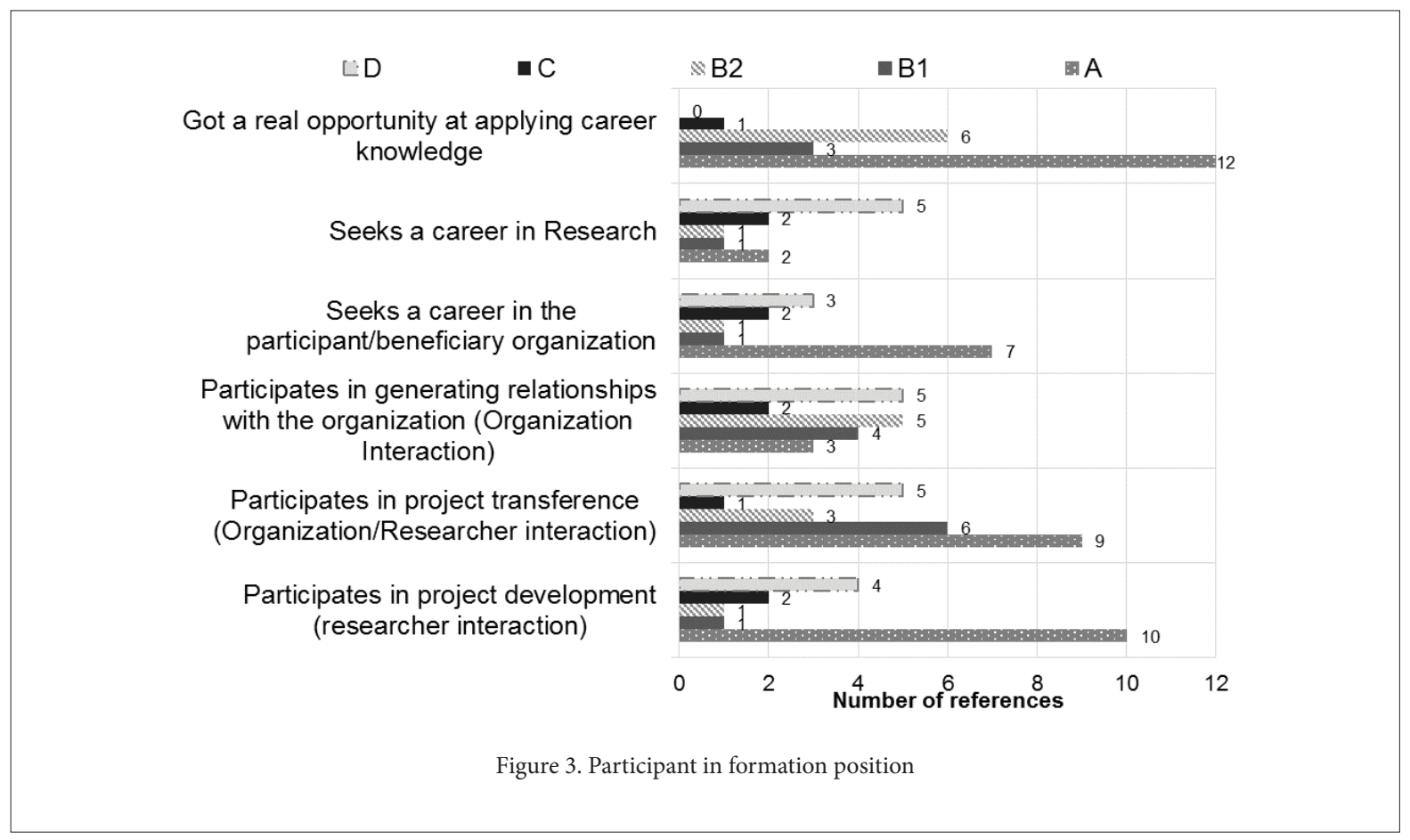

ISSN: 0718-2724. (http://jotmi.org) 
When referring to participant organization's profile in RTRC it is observed that universities $\mathrm{A}, \mathrm{B} 1$, and $\mathrm{D}$ relate in greater measure to private sector organizations (Hanel \& St-Pierre, 2006), and they are also catalogued as large industries (Hanel \& St. Pierre, 2006; Meyer-Krahmer \& Schmoch 1998) while university B2, works mostly with guilds and university $\mathrm{C}$ works with the public sector (fig. 4).

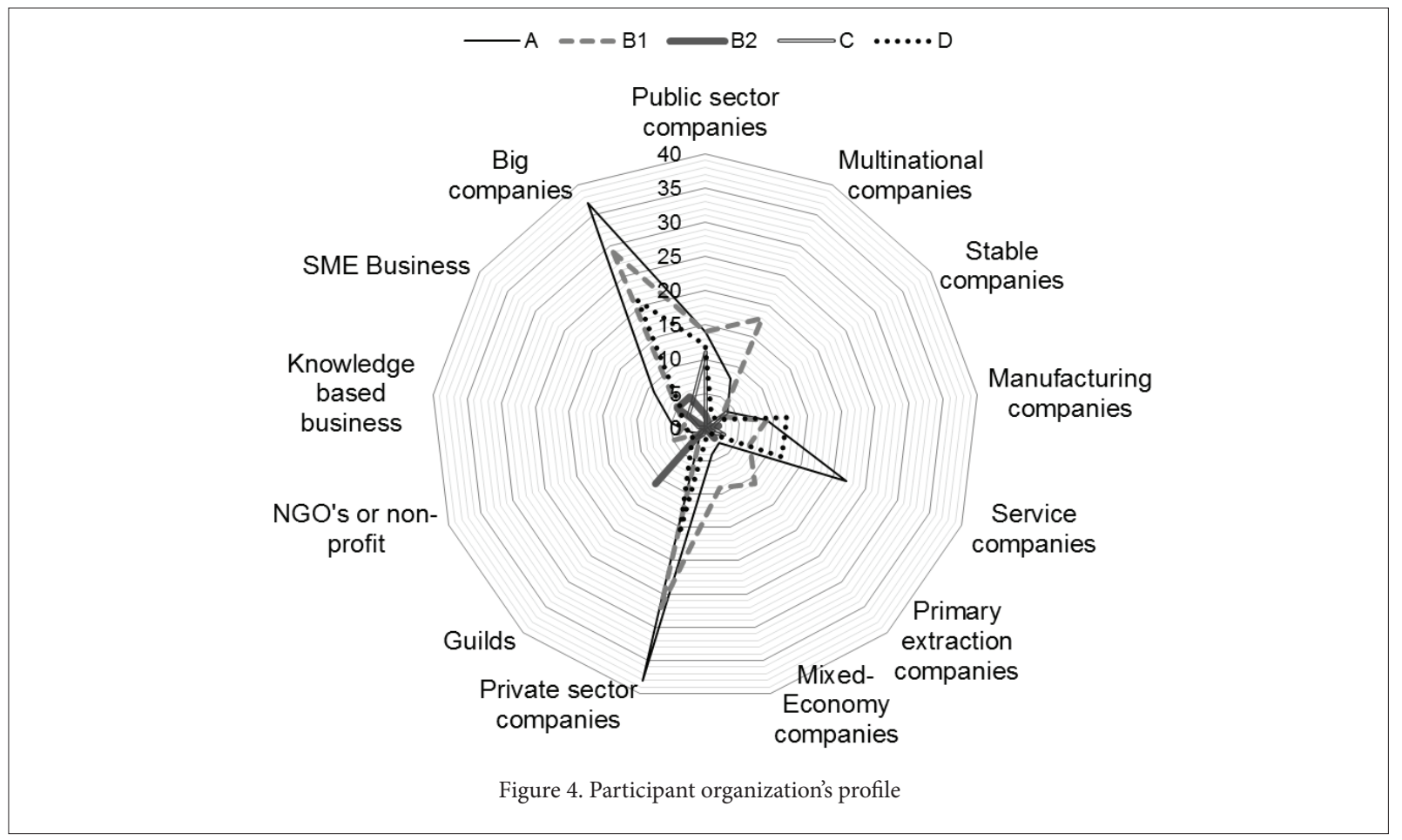

In regard to positions that organizations assume and their capabilities when it comes to RTRC, it is evidenced that most of them have processes that invest in R\&D activities (Y. Lee, 2000) which allows them to commit to the economic and organizational support of $\mathrm{R} \& \mathrm{D}+\mathrm{I}$
(Heidrick et al., 2005) when organizations are linked to RC processes as it has been evidenced, the link is made through trust relationships with the researcher (Gertner et al., 2011; Krucken et al., 2007; Lakpetch \& Lorsuwannarat, 2012) (Fig. 5).

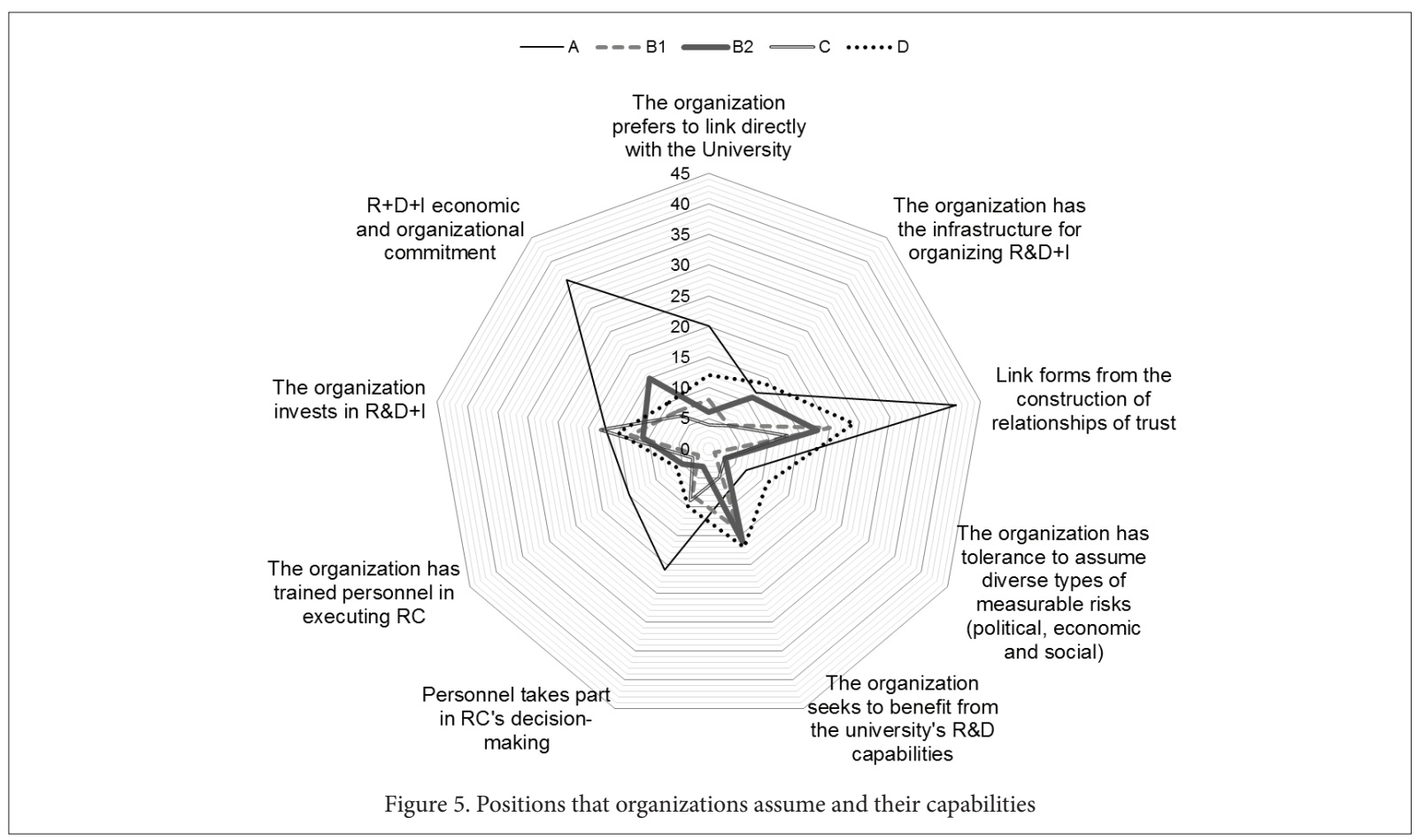

ISSN: 0718-2724. (http://jotmi.org) 
Up until this point, four main actors or main participants in a RC process have been studied and a researcher's profile that is more industry oriented has been identified, this profile seeks to complement teaching and research from the relationship there is with the private sector; participants in formation that link themselves to projects related to their dissertations so that they can apply their knowledge in real settings and get a better contact with the industry while doing so (or start either a career in the industry or in research) and as a majority, they link to private organizations that have the resource and the openness to work with academia and take advantage of the knowledge this latter one generates.

\section{$\mathrm{R}+\mathrm{D}$ Transfer and development process}

Another aspect to take into account is the process in which RTRC takes place, one key factor is a project planning, this phase establishes initial conditions for execution (fig. 6). Every University has a planning process (Acevedo et al., 2005; Burnside \& Witkin, 2008; Jaramillo, 2005; Morandi, 2013) where several meetings happen to ensure a proper follow-up on project advancements, another important aspect to consider is establishing previous agreements on industrial property (Morandi, 2013; Silvernagel et al., 2009) that may come up at the beginning of the project itself.

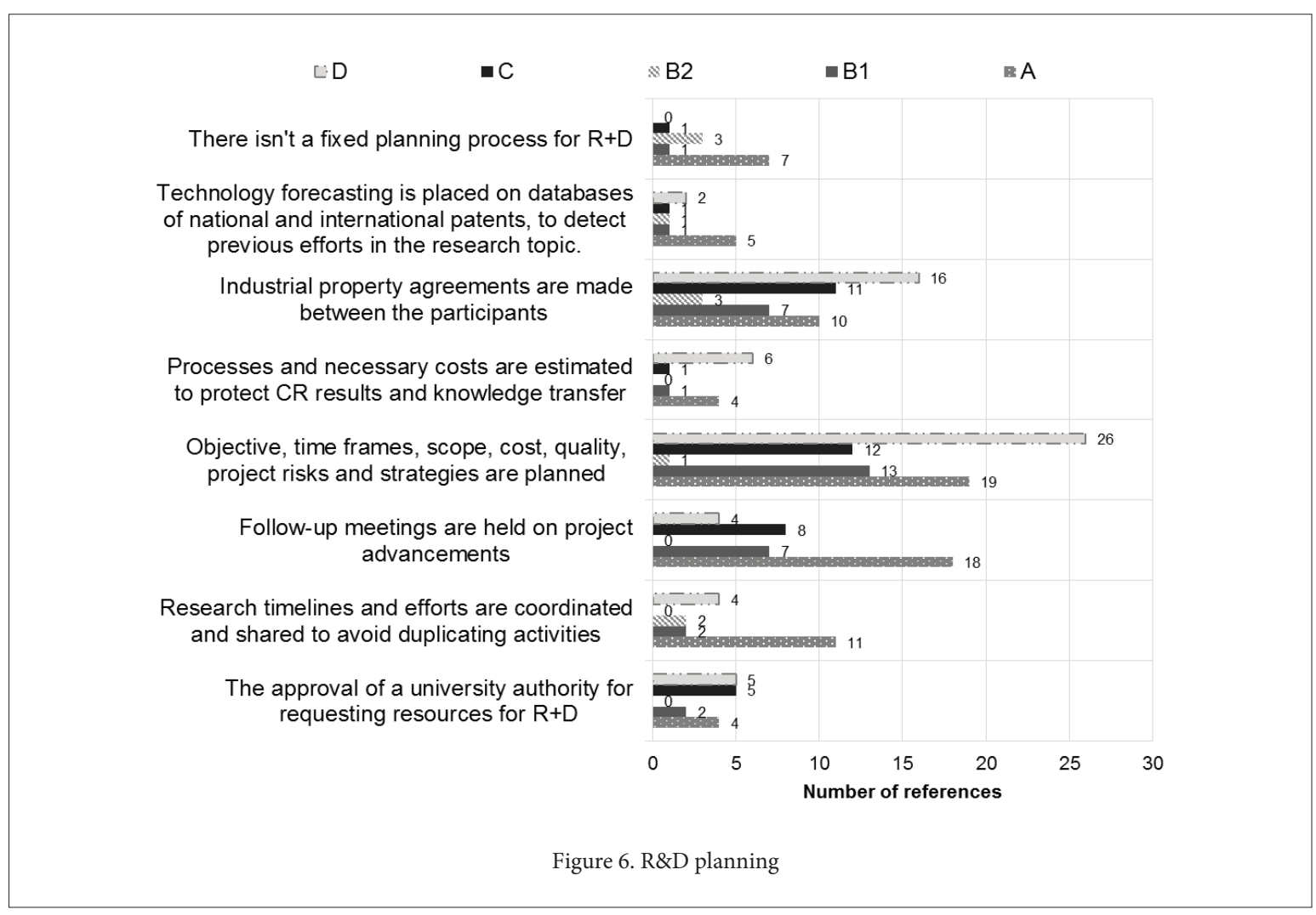

Multiple actor participation is also a very important aspect to take into account in a joint development effort (Burnside \& Witkin, 2008; Krucken et al., 2007) for all the universities that took part on the study, there are cases where one of the parts takes on development, which means that either the university or the organization would lead and develop the project at hand, this is mostly true for universities A, B1 and $\mathrm{C}$, academic development with industry instructions (Krucken et al., 2007). Participative research is also evidenced in universities A, B2 and C. Projects in which the development is the hands of several organizations is not evidenced in spite of university B2 having experiences in which not only academia and productive sector work together, but other scientific organizations have taken part in the development of a project as well as the resultant transfer for the research.
In the state of appropriation and transfer, university A shows that their projects are still in the development process or have been taking away to different contexts and external organizations have shown interest in the development process. Projects in university B1 are in a stage of consolidation and product generation that can be transferred; this means that the research still has not left the university. University B2 indicates that projects are generating impact on a regional level (Bozeman, 2000). Universities $\mathrm{C}$ and $\mathrm{D}$ give greater importance to the transfer as a way to increase participant personnel capabilities (Bozeman, 2000; Siegel et al., 2004) (fig. 7). 


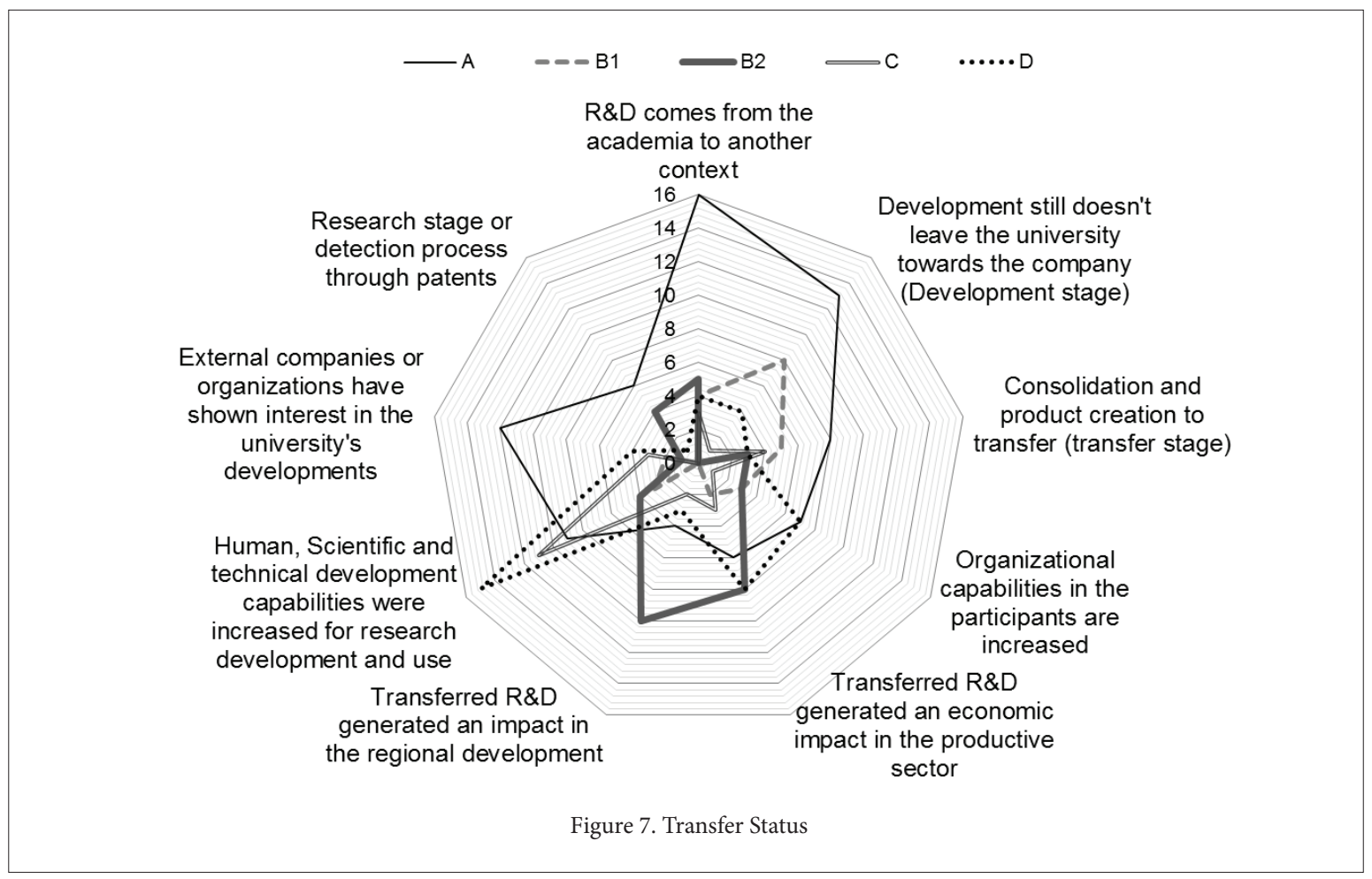

When it comes to knowledge appropriation, three universities (A, B2 and $\mathrm{D}$ ) show that the development has already been appropriated by the industry, which means that the latter one is at this point in a position to replicate the research. Universities A and B1 define appropriation in diffusion via joint publications. University B2 takes into account the social acknowledgment (Acevedo et al., 2005) that their developments have had in their endeavors. University C points out that they are at this point in bargaining processes with the industry (Payumo et al., 2012) while University D has already licensed their findings (Siegel et al., 2004) (fig. 8).

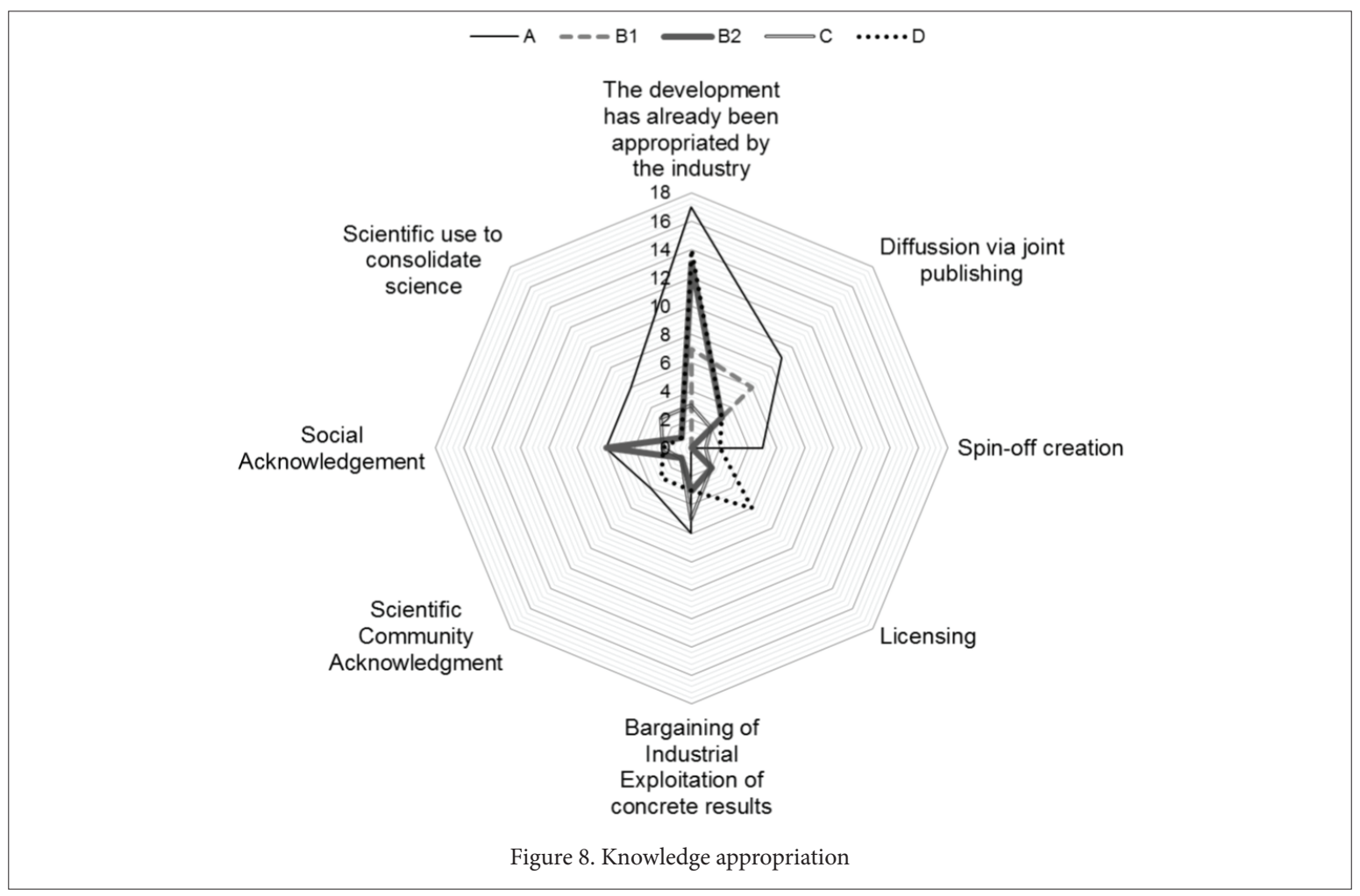

ISSN: 0718-2724. (http://jotmi.org) 


\section{Universities Internal Capabilities}

When it comes to policies that favor RTRC, three factors have been found to be of importance, first there are the actions that the university takes to motivate their academic body, then there is establishing an active relationship with their surroundings through diverse channels (Dooley \& Kirk, 2007; Fernández et al., 2000) and finally, counting with a direction that adapts to the changes in the environment. These three factors are traits of entrepreneurial universities (Fernández et al., 2009) and make explicit appreciations in universities A, B1, C and D. However, the entrepreneurial institution capability (Krucken et al., 2007; Fernández et al., 2000) was not referenced significantly from those who are beneficiaries.
In resources and capabilities for RC (in number of references for those interviewed) difficulties in administrative processes are seen as a limiting factor in RTRC since they put a strain on research processes (when it's time to assign physical, economic and personnel resources) as well as times of project execution (severely affected by academic calendars). Quoting one of our interviewees, "The university deals in semesters, while the industry deals in seconds" this is clear evidence that times in academia and the industry are still a limiting factor for collaboration and creation of trust and commitment bonds between these two. The existence of economic and personnel resources is also pointed out for RC (Jaramillo, 2005; Siegel et al., 2004) especially in universities B and D. Universities A, B1, C and $\mathrm{D}$ establish as a thriving resource the proper infrastructure so that the $\mathrm{R}+\mathrm{D}$ comes to fruition (Jaramillo, 2005; Siegel et al., 2004)

University perspectives on RTRC (fig. 9) are different depending on the university even though all of them are driven to strengthen knowledge processes and knowledge transfer. Universities A, B1, and D consider that research should increase economic funds in the university and for their students. Research is costly and the government budget for R\&D is not enough or convenient for project initiatives in research groups (due to slow processing times or required confidentiality by the organization) this situation drives the search for alternative funding means for the research to the point that, university $\mathrm{D}$ has pointed out that they have managed to handle the process with enough resources as to favor the teaching mission (through Ph.D. Scholarships for their students) through university funds. B2 University seeks to improve transference processes under the industrial property model while University $C$ is driven by the need to transfer knowledge to its surroundings.

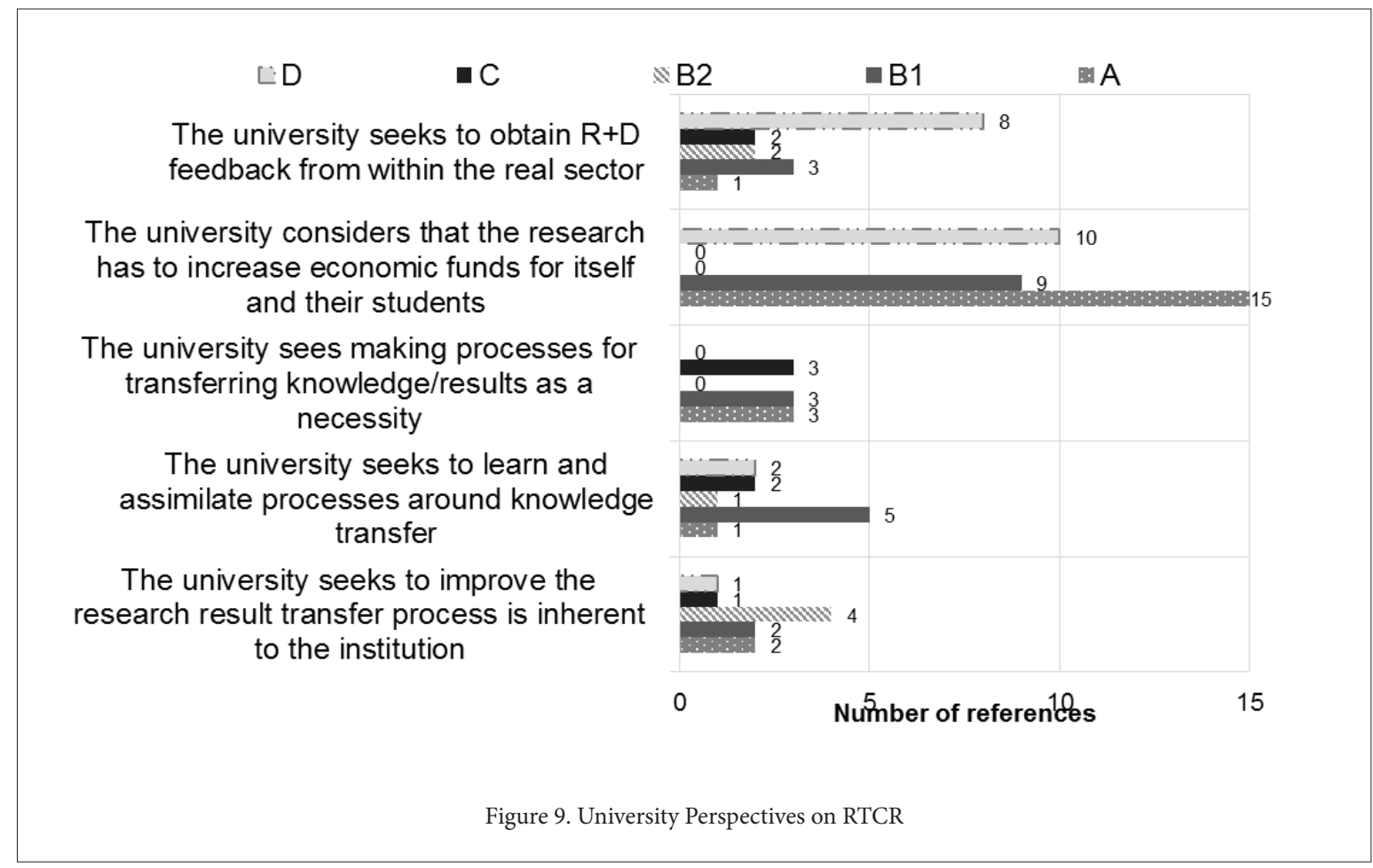

In conclusion, Universities A and D have a greater capability for RTRC processes as well as to generate an active relationship with the productive sector since their policies are oriented to create mechanisms that belong to the entrepreneurial university model and the resources they have had allowed for collaborative processes. Universities $B$ and $C$ want to strengthen their capabilities, but they have several limitations in their processes and internal organization in the university. 


\section{Surrounding conditions (organizations, society and State)}

When speaking of the conditions generated by organizations and the productive sector to favor the RC, they are overall positive since organizations have a better relationship with academia and they see a favorable link with it to the point that they see this relationship as a means to support economic ends (Heidrick et al., 2005; Hanel \& St. Pierre, 2006; Vestergaard, 2007) and this generates initiatives to know about the R\&D+I activities in the university (Arvanitis et al., 2011) (fig. 10).

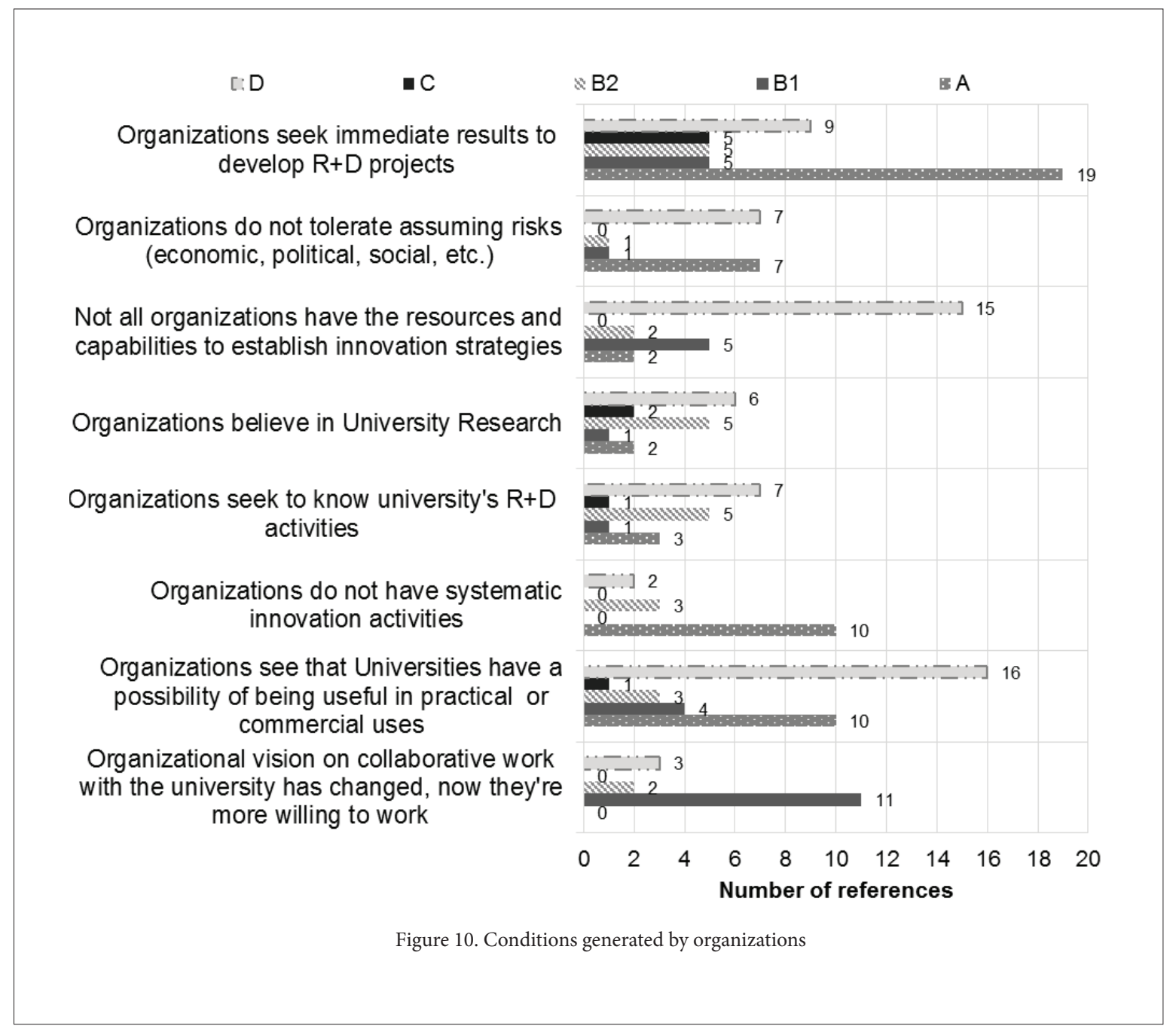

Among the negative aspects that affect said conditions are the capabilities of the productive sector to generate and appropriate $\mathrm{R}+\mathrm{D}+\mathrm{I}$ since it is the big, private companies that have the possibility to create links with academia and the work that can be made with SME's is limited due to the resources and internal capabilities to manage $\mathrm{R}+\mathrm{D}$ (Garcia, 2008; Kawasaki, 2009; Lai, 2011). Organizations still see the usage of different time frames as a limitation (Vestergaard, 2005) since their workflow is affected by the slow and interrupted time settings that universities work with.
On State-generated conditions, interviewees from universities A and $\mathrm{D}$ point out that in spite of having the resources for $\mathrm{R}+\mathrm{D}$ (Azagra, 2003; Geiger \& Creso, 2005; Vestergaard, 2007) the State has not made the connection between the university and the industry easy and also the regulations for public universities has not been clear in the creation of spin-offs for academics or the use of royalties for research among others. Universities B1 and D have also pointed out that the resources for science, research and technology have been "politicized" (fig. 11). 


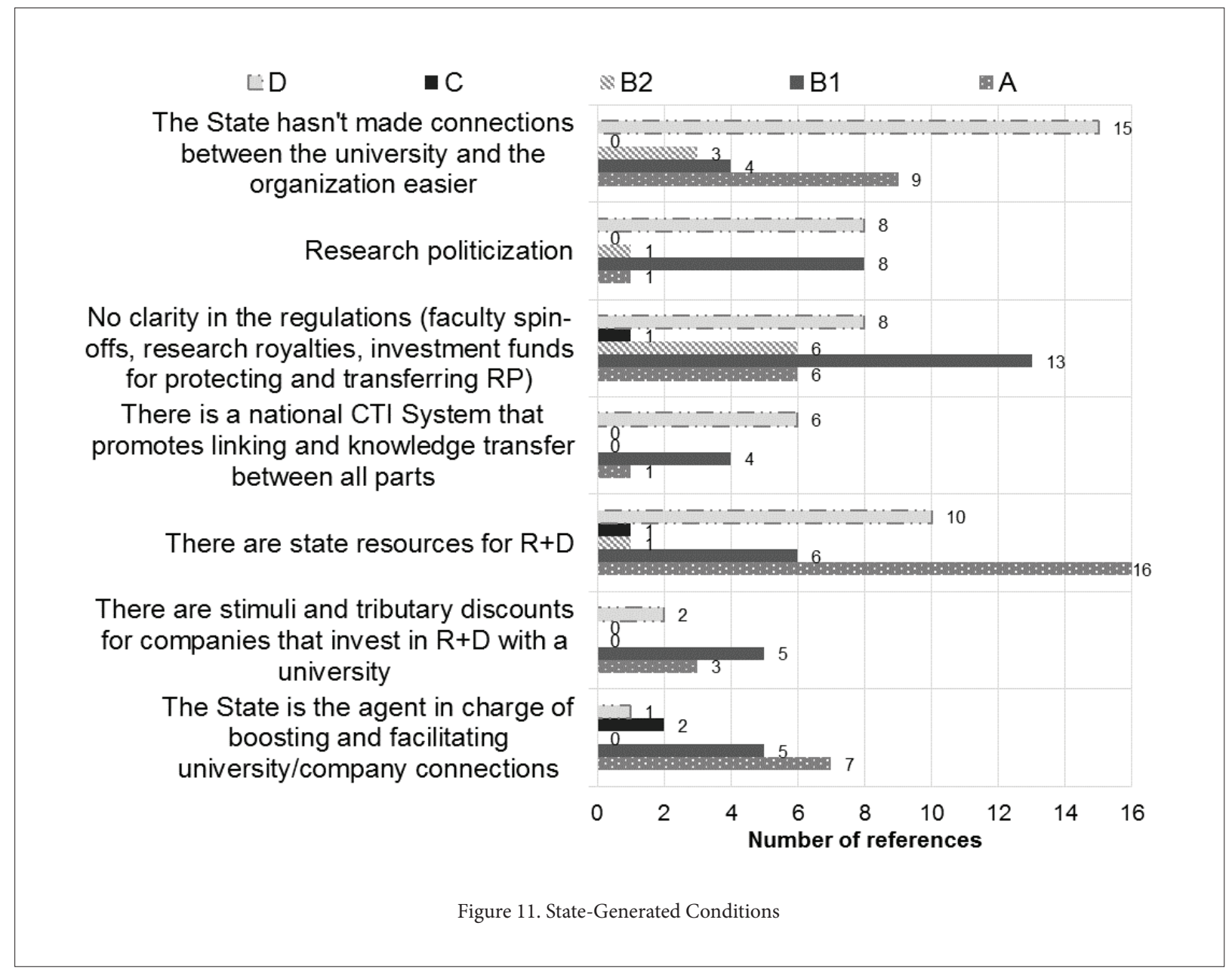

University A stands out on the Society-generated conditions in their aversion to risk (Jaramillo, 2005; Vestergaard, 2007; Garcia, 2008) which is associated with the fact that there is an uncertainty in investing resources in scientific developments. On the other hand, Universities A and B2 identify resources for research are scarce (in spite of State efforts). Universities B2 and C indicate that there are barriers for commercializing developments due to cultural resistance, high cost or competitiveness in the market. Opposing what has been said before, Universities $\mathrm{B} 1$ and $\mathrm{D}$ see a more favorable environment since they have several entities supporting their RC endeavors and they also have the same societal challenges to generate applied knowledge as the others.

Thus, surroundings conditions significantly impact the development of CR in universities. The State is the one handing out resources for research, but it does not establish a clear and sustainable system $\mathrm{R}+\mathrm{D}$ and the general academia-industry-environment relationship. The productive sector is also cautious in developing research with universities and the technology appropriation, in spite of all of this, the cases that were subjected to study show an effective CR model even though the environment may not be the best because of integration barriers between science and technology developers and organizations.

\section{Discussion}

The selection of driving factors came down to those who had more references during the interviews conducted as well as those with more incidence in RC and RTRC (table 7). 
Table 7. Determining Factors in Research Results Transfer in Collaborative Research

\begin{tabular}{|c|c|c|c|}
\hline \multicolumn{4}{|c|}{ Participant's Profile } \\
\hline \multicolumn{2}{|l|}{ Researcher's profile } & \multicolumn{2}{|c|}{ Researcher's position } \\
\hline \multicolumn{2}{|l|}{ Committed to the needs of the productive ally } & \multicolumn{2}{|c|}{$\begin{array}{l}\text { Open to participate in research agreements, committees, incubator extensions } \\
\text { and collaborative } \mathrm{R}+\mathrm{D}\end{array}$} \\
\hline \multicolumn{2}{|l|}{ Student's profile } & \multicolumn{2}{|l|}{ Student's Position } \\
\hline \multicolumn{2}{|l|}{ Linked to the project through research } & \multicolumn{2}{|c|}{ Takes part in project transference (researcher and organization interaction) } \\
\hline \multicolumn{2}{|l|}{ Belongs to private sector } & \multirow{2}{*}{\multicolumn{2}{|c|}{ Links are made via trust relationships }} \\
\hline \multicolumn{2}{|l|}{ Big Companies } & & \\
\hline \multicolumn{4}{|c|}{ University conditions } \\
\hline Focus & Linking Units & & Linking unit personnel profile \\
\hline Technical and Scientific personnel training & Research or Tech & 1 transfer/IP Office & knowledge on industrial intellectual property \\
\hline \multicolumn{4}{|c|}{ University Policies } \\
\hline \multicolumn{4}{|c|}{ The university encourages patenting } \\
\hline \multicolumn{4}{|c|}{ The university creates action plans, programs, projects and call-outs for Collaborative Research and Knowledge transfer } \\
\hline \multicolumn{4}{|c|}{ The university has a director's board that is open to changes } \\
\hline \multicolumn{4}{|c|}{ Establish an active relationship with their surroundings through diverse channels } \\
\hline \multicolumn{4}{|c|}{ There is a plan to follow-up on linking development } \\
\hline \multicolumn{4}{|c|}{$\mathrm{R}+\mathrm{D}$ Process } \\
\hline
\end{tabular}

Linking mechanisms or strategies

E-U Formal structure (agreements, contracts)

\section{The pursuit of knowledge application in a real context}

Establishing Formal relationships Academia-Environment

\section{$\mathrm{R}+\mathrm{D}$ motivation}

Useful subject selection in terms of social context

Planning

Objectives, time frame, scope, costs, quality and project risks and strategies are set

\section{Medium conditions}

\section{Organizational conditions}

Organizations see that universities have the potential to be useful

\section{State Conditions}

The State has $\mathrm{R}+\mathrm{D}$ resources

\section{Environment conditions}


Participant profile shows an openness to establish CR relationships, which has driven the university to generate capabilities to support these processes (from adopting a focus towards CR complementary to formation activities to creating policies that go in favor of the profile of the entrepreneurial university) and seek to position themselves as an institution that actively participates in the innovation system of the region (Colyvas, 2007).

The existence of linking or transfer units favors CR and RTCR due to the fact that it serves as an integrating mechanism among the main actors. These units are important on several levels: research groups, internal transfer offices or units that facilitate financing processes and management to the national level.

CR and RTCR processes start by creating a trust relationship (informal) between the two parts and then formalizing it by a strict planning process that generates total clarity according to project expectations.

The main motivation of universities when generating links between academia and the productive sector is the contribution of science to a real context and the generation of a benefit to society.

The results of the universities that were subjected to study, are coherent with the general aspects found in the literature on CR and RTCR processes, however, state and appropriation of $R \& D$ in the different cases of study are aspects in which barriers are present, this is due to the fact that the results have not been transferred in its totality in spite of the industry's interest.

Finally, organizations now visualize the activities in universities more closely as integrators of their internal processes to which they are more interested in the knowledge offer they may bring. State powers the system with $R \& D$ resources and the market pulls towards the use of knowledge as a factor of productivity and competitiveness.

\section{Acknowledgements}

University employees linked to the different participating universities: Universidad Nacional de Colombia in Bogotá and Medellín, Universidad de Antioquia, Universidad del Valle in Cali and Universidad Militar Nueva Granada in Bogotá, as well as the employees of the participating companies who offered their time and knowledge to identify the different cases and describe the transference experiences in which they had been part of. Also Mr. Danilo Nava, for translating this document. This is a research article derived from the INV ECO 1480 Project: Determining factors in the transference of research results via Collaborative Research towards the productive sector in four Colombian public universities. Funded by Research Vice dean in Universidad Militar Nueva Granada, 2014 validity.

\section{References}

Acevedo, M., González, O., Zamudio, L., Abello, R., Camacho, J., Gutiérrez, M., . . Baeza, Y. (2005). Un análisis de la transferencia y apropiación del conocimiento en la investigación de universidades colombianas. Investigación y Desarrollo, 13(1), 128-157.
Arvanitis, S., Kubli, U., \& Wörter, M. (2011). Knowledge and Technology Transfer Activities between Firms and Universities in Switzerland: An Analysis Based on Firm Data. Industry and Innovation, 18(4), 369-392. doi: 10.1080/13662716.2011.573956

Azagra, J. (2003). La contribución de las universidades a la innovación: Efectos del fomento de la interacción universidad-empresa y las patentes universitarias. (Doctoral), Universitat de Valencia, Valencia.

Bjerregaard, T. (2009). Universities-industry collaboration strategies: a micro-level perspective. European Journal of Innovation Management, 12(2), 161-176. doi: doi:10.1108/14601060910953951

Bozeman, B. (2000). Technology transfer and public policy: a review of research and theory. Research Policy, 29(4-5), 627-655. doi: http:// dx.doi.org/10.1016/S0048-7333(99)00093-1

Burnside, B., \& Witkin, L. (2008). Forging Successful University \& Industry Collaborations. Research-Technology Management, 51(2), 26-30.

Cabrero, E., Cárdenas, S., Arellano, D., \& Ramírez, E. (2011). La vinculación entre la universidad y la industria en México: Una revisión a los hallazgos de la Encuesta Nacional de Vinculación. Perfiles educativos, 33, 187-199.

Colyvas, J. A. (2007). From divergent meanings to common practices: The early institutionalization of technology transfer in the life sciences at Stanford University. Research Policy, 36(4), 456-476. doi: http://dx.doi.org/10.1016/j.respol.2007.02.019

D'Este, P., \& Patel, P. (2007). University-industry linkages in the UK: what are the factors underlying the variety of interactions with industry? Research Policy, 36(9), 1295-1313.

Davies, H., Nutley, S., \& Walter, I. (2008). Why 'knowledge transfer' is misconceived for applied social research.J Health Serv Res Policy, 13(3), 188-190. doi: 10.1258/jhsrp.2008.008055

Decter, M., Bennett, D., \& Leseure, M. (2007). University to business technology transfer-UK and USA comparisons. Technovation, 27(3), 145-155. doi: http://dx.doi.org/10.1016/j.technovation.2006.02.001

Dooley, L., \& Kirk, D. (2007). University-industry collaboration: Grafting the entrepreneurial paradigm onto academic structures. European Journal of Innovation Management, 10(3), 316-332. doi: doi:10.1108/14601060710776734

Fernández, I., Castro, E., Conesa, F., \& Gutiérrez, A. (2000). Las relaciones universidad-empresa: entre la transferencia de resultados y el aprendizaje regional. Revista Espacios, 21, 127-147.

Fernández López, S., Otero González, L., Rodeiro Pazos, D., \& Rodríguez Sandiás, A. (2009). Determinantes de la capacidad de las universidades para desarrollar patentes. Revista de la educación superior, 38, 7-30. 
Garcia, G. A. (2008). La propiedad intelectual en las economías universitarias. Revista De La Facultad De Derecho y Ciencias Políticasv, 38(108), 53-72.

Geiger, R. L., \& Creso, S. (2005). Beyond technology transfer: US state policies to harness university research for economic development. Minerva, 43(1), 1-21.

Gertner, D., Roberts, J., \& Charles, D. (2011). University-industry collaboration: a CoPs approach to KTPs. Journal of Knowledge Management, 15(4), 625-647. doi: doi:10.1108/13673271111151992

Hanel, P., \& St-Pierre, M. (2006). Industry-University Collaboration by Canadian Manufacturing Firms*. The Journal of Technology Transfer, 31(4), 485-499. doi: 10.1007/s10961-006-0009-5

Heidrick, T. R., Kramers, J. W., \& Godin, M. C. (2005). Deriving Value from Industry-University Partnerships: A Case Study of the Advanced Engineering Materials Centre. Engineering Management Journal, 17(3), 26-32. doi: 10.1080/10429247.2005.11415294

Jaramillo, L. J. (2005). Las políticas universitarias: para la promoción de vinculaciones con el sector empresarial en I\&D Caso de Colombia : documento de trabajo: Asociación Colombiana de Universidades.

Kazumasa, K. (2009). University-Industry Research Collaborations of SmallMedium Enterprises - An Insight from Japan. IETE Technical Review.

Krücken, G., Meier, F., \& Müller, A. (2007). Information, cooperation, and the blurring of boundaries - technology transfer in German and American discourses. Higher Education, 53(6), 675-696. doi: 10.1007/ s10734-004-7650-4

Lai, W.-H. (2011). Willingness-to-engage in technology transfer in industry-university collaborations. Journal of Business Research, 64(11), 1218-1223. doi: http://dx.doi.org/10.1016/j.jbusres.2011.06.026

Lakpetch, P., \& Lorsuwannarat, T. (2012). Knowledge transfer effectiveness of university-industry alliances. International Journal of Organizational Analysis, 20(2), 128-186. doi: doi:10.1108/19348831211227819

Lee, Y. (2000). The Sustainability of University-Industry Research Collaboration: An Empirical Assessment. The Journal of Technology Transfer, 25(2), 111-133. doi: 10.1023/A:1007895322042

Lee, Y. S. (1996). 'Technology transfer' and the research university: a search for the boundaries of university-industry collaboration. Research Policy, 25(6), 843-863. doi: http://dx.doi.org/10.1016/00487333(95)00857-8

Markman, G. D., Gianiodis, P. T., Phan, P. H., \& Balkin, D. B. (2005). Innovation speed: Transferring university technology to market. Research Policy, 34(7), 1058-1075. doi: http://dx.doi.org/10.1016/j. respol.2005.05.007

Meyer-Krahmer, F., \& Schmoch, U. (1998). Science-based technologies: university-industry interactions in four fields. Research Policy, 27(8), 835-851. doi: http://dx.doi.org/10.1016/S0048-7333(98)00094-8

Morandi, V. (2013). The management of industry-university joint research projects: how do partners coordinate and control R\&D activities? The Journal of Technology Transfer, 38(2), 69-92. doi: 10.1007/s10961-011-9228-5

OECD. (2004). Patents and Innovation: Trends and Policy Challenges. Paris: OECD Publishing.

Payumo, J., Gang, Z., Pulumbarit, E., Jones, K., Maredia, K., \& Grimes, H. (2012). Managing intellectual property and technology commercialization: Comparison and analysis of practices, success stories and lessons learned from public research universities in developing Asia. Innovation, 14(4), 478-494. doi: 10.5172/ impp.2012.14.4.478

Perkmann, M., \& Walsh, K. (2007). University Industry Relationships and Open Innovation: Towards a Research Agenda. International Journal of Management Reviews, 9(4), 259-280.

Pineda, K., Morales, M., \& Ortiz, M. (2011). Modelos y mecanismos de interacción universidad-empresa-Estado: retos para las universidades colombianas. . Revista Universidad de La Salle, 56, 41-67

Ponomariov, B., \& Boardman, C. (2008). The effect of informal industry contacts on the time university scientists allocate to collaborative research with industry. The Journal of Technology Transfer, 33(3), 301-313. doi: 10.1007/s10961-007-9029-z

Ramos-Vielba, I., \& Fernández-Esquinas, M. (2012). Beneath the tip of the iceberg: exploring the multiple forms of university-industry linkages. Higher Education, 64(2), 237-265. doi: 10.1007/s10734-011-9491-2

Saavedra, M. (2009). Problemática y desafíos actuales de la vinculación universidad empresa: El caso mexicano. Actualidad contable FACES, 12(19), 100-119.

Siegel, D. S., Waldman, D. A., Atwater, L. E., \& Link, A. N. (2004). Toward a model of the effective transfer of scientific knowledge from academicians to practitioners: qualitative evidence from the commercialization of university technologies. Journal of Engineering and Technology Management, 21(1-2), 115-142. doi: http://dx.doi. org/10.1016/j.jengtecman.2003.12.006

Silvernagel, C., Schultz, R. R., \& Moser, S. B. (2009). Studentgenerated intellectual property: perceptions of ownership by faculty and students. Journal of Entrepreneurship Education, 12, 13-33.

Thune, T. (2009). Doctoral students on the university-industry interface: a review of the literature. Higher Education, 58(5), 637-651. doi: 10.1007/s10734-009-9214-0

Vestergaard, J. (2005). Innovation and university interaction with industry in Colombia : policies, experiences and future challenges W. Bank (Ed.) (pp. 113). 